\title{
Management of proteinuria in the transplanted patient
}

\author{
Tomáš Seeman
}

Received: 3 February 2014 / Revised: 23 May 2014 / Accepted: 3 June 2014 / Published online: 27 August 2014

(C) IPNA 2014

\begin{abstract}
Proteinuria is a relatively frequent complication in children after renal transplantation (40-80\%). It is usually mild and non-nephrotic in nature and predominantly tubular in origin. The major causes of post-transplant proteinuria are recurrence of primary glomerulonephritis [mostly focal segmental glomerulosclerosis (FSGS)], rejection (acute and chronic), mTOR inhibitors or hypertension. Proteinuria is a risk factor for graft loss and patient death in adults, and even a mild proteinuria (0.1-0.2 g/day) is associated with impaired graft and patient survival. In children, proteinuria seems to be associated with graft but not patient survival. Proteinuria (protein/creatinine ratio) should be assessed regularly in all children. In children with prior chronic kidney disease due to idiopathic FSGS, proteinuria should be assessed daily during the first month after transplantation to enable early diagnosis of recurrence. The cause of proteinuria should be identified, and graft biopsy should be considered in children with unexplained proteinuria, especially with new onset proteinuria or deterioration of previously mild proteinuria. Treatment must be primarily targeted at the cause of proteinuria, and in normotensive children symptomatic antiproteinuric therapy with angiotensinconverting enzyme inhibitors/angiotensin II receptor antagonists should also be initiated. Other antihypertensive drugs should be used to achieve target blood pressure of $<75$ th percentile. Target proteinuria should be $<20 \mathrm{mg} / \mathrm{mmol}$ creatinine.
\end{abstract}

\footnotetext{
T. Seeman $(\square)$

Department of Pediatrics and Transplantation Center, 2nd Faculty of Medicine-University Hospital Motol, Charles University in Prague, V Úvalu 84, 15006 Prague, Czech Republic

e-mail: tomas.seeman@1fmotol.cuni.cz

T. Seeman

Biomedical Center, Faculty of Medicine in Plzen, Charles University in Prague, Plzen, Czech Republic
}

Keywords Proteinuria $\cdot$ Children $\cdot$ Renal transplantation · Graft survival $\cdot$ Blood pressure $\cdot$ Hypertension . Angiotensin-converting enzyme inhibitors

\section{Introduction}

Proteinuria is a common complication in most chronic kidney diseases (CKD) and together with hypertension is the most important risk factor for progression of native kidney diseases [1-3]. In recent years there has been an increasing interest in the role of proteinuria also in patients after renal transplantation, as it has been demonstrated that it is an important and potentially treatable risk factor for graft loss and patient mortality [4].

The aim of this review is to summarize the management of proteinuria in patients after renal transplantation.

\section{Prevalence of post-transplant proteinuria and methods for its measurement}

Proteinuria is a common complication in patients after renal transplantation (RTx). The prevalence of proteinuria reported in different studies on adult and pediatric populations varies considerable, from 11 to $82 \%$ [4-13]. The main reason for this wide variation in prevalence of proteinuria is the different threshold used in these studies to define proteinuria. In studies involving adult populations which used a very liberal threshold of $2-3 \mathrm{~g} /$ day, prevalence was only $10-15 \%[5,7]$. In contrast, studies that used a threshold similar to that used for non-transplanted patients $(0.15-0.25 \mathrm{~g} /$ day $)$ revealed proteinuria in $31-45 \%$ of patients $[4,11]$.

In children, proteinuria has been investigated in only a limited number of studies [14-17]. In one of these studies proteinuria was detected in $100 \%$ of children 1 week after 
transplantation when the threshold was $200 \mathrm{mg} / \mathrm{g}$ creatinine [16]. In two other studies proteinuria was detected in $47-82 \%$ of patients at least 6 months after RTx using the threshold of $0.096 \mathrm{~g} / \mathrm{m}^{2} /$ day or $22 \mathrm{mg} / \mathrm{mmol}$ creatinine $[15,17]$. This prevalence is higher than that found in adult studies; however, when a threshold of $0.960 \mathrm{~g} / \mathrm{m}^{2} /$ day was used, which corresponds with a threshold of about $2 \mathrm{~g} /$ day, the prevalence was only $12 \%$ and corresponds with the prevalence in adults at this threshold [15]. The prevalence of post-transplant proteinuria according to different thresholds in different studies is summarized in Fig. 1.

The currently recommended method to assess total proteinuria in children with CKD is to determine the protein/creatinine ratio in a random urine sample, with a threshold of $20 \mathrm{mg} / \mathrm{mmol}$ creatinine, i.e. $200 \mathrm{mg} / \mathrm{g}$ creatinine $[18,19]$. The threshold in $24-\mathrm{h}$ urine collection is $96 \mathrm{mg} / \mathrm{m}^{2} /$ day for children and $150 \mathrm{mg} /$ day for adults. The currently recommended method to assess the glomerular type of proteinuria (albuminuria) is determination of the albumin/creatinine ratio, with a threshold of $3 \mathrm{mg} /$ mmol creatinine, i.e. $30 \mathrm{mg} / \mathrm{g}$ creatinine $[18,19]$. The tubular type of proteinuria is usually assessed by measuring the urinary excretion of microglobulins, such as alpha1-microglobulin or beta-2-microglobulin, with a threshold of 0.55 and $0.04 \mathrm{mg} / \mathrm{mmol}$ creatinine for alpha-1microglobulinuria and beta-2-microglobulin, respectively. These same methods and thresholds should also be used in transplanted children. The methods and thresholds for proteinuria are summarized in Table 1.

\section{Types of post-transplant proteinuria}

Proteinuria can be classified according to the time of onset, persistency, quality (glomerular or tubular origin), quantity (degree) and cause.

Early proteinuria is very common in transplanted patients. In a pediatric study by Chua et al., $100 \%$ of children had proteinuria at 1 week after RTx; however, it disappeared in $70 \%$ of patients at 8-9 weeks posttransplant [16]. Such transient proteinuria does not have negative impact on long-term graft survival $[6-8,20]$. To the contrary, later onset proteinuria $(>2-3$ months posttransplant) or persistent proteinuria (duration $>3$ months) does have a negative impact on long-term graft survival (see below section Clinical consequences).

The origin of proteinuria (i.e. glomerular or tubular) has been investigated in several studies [17,21-23]. Most of these have demonstrated that the predominant type of proteinuria in transplanted patients is tubular in origin, occurring in up to 79 and $80 \%$ of adult and pediatric transplant patients, respectively. There is an inverse relationship between total proteinuria and tubular proteinuria, with the lower the total proteinuria, the higher the percentage of tubular proteinuria, and vice versa [23]. On the other hand, glomerular proteinuria with increased albuminuria can signal primary glomerular injury, such as recurrence of de novo glomerular disease, transplant glomerulopathy, hypertension-induced glomerulopathy (hypertensive nephropathy of the graft) or chronic allograft nephropathy.

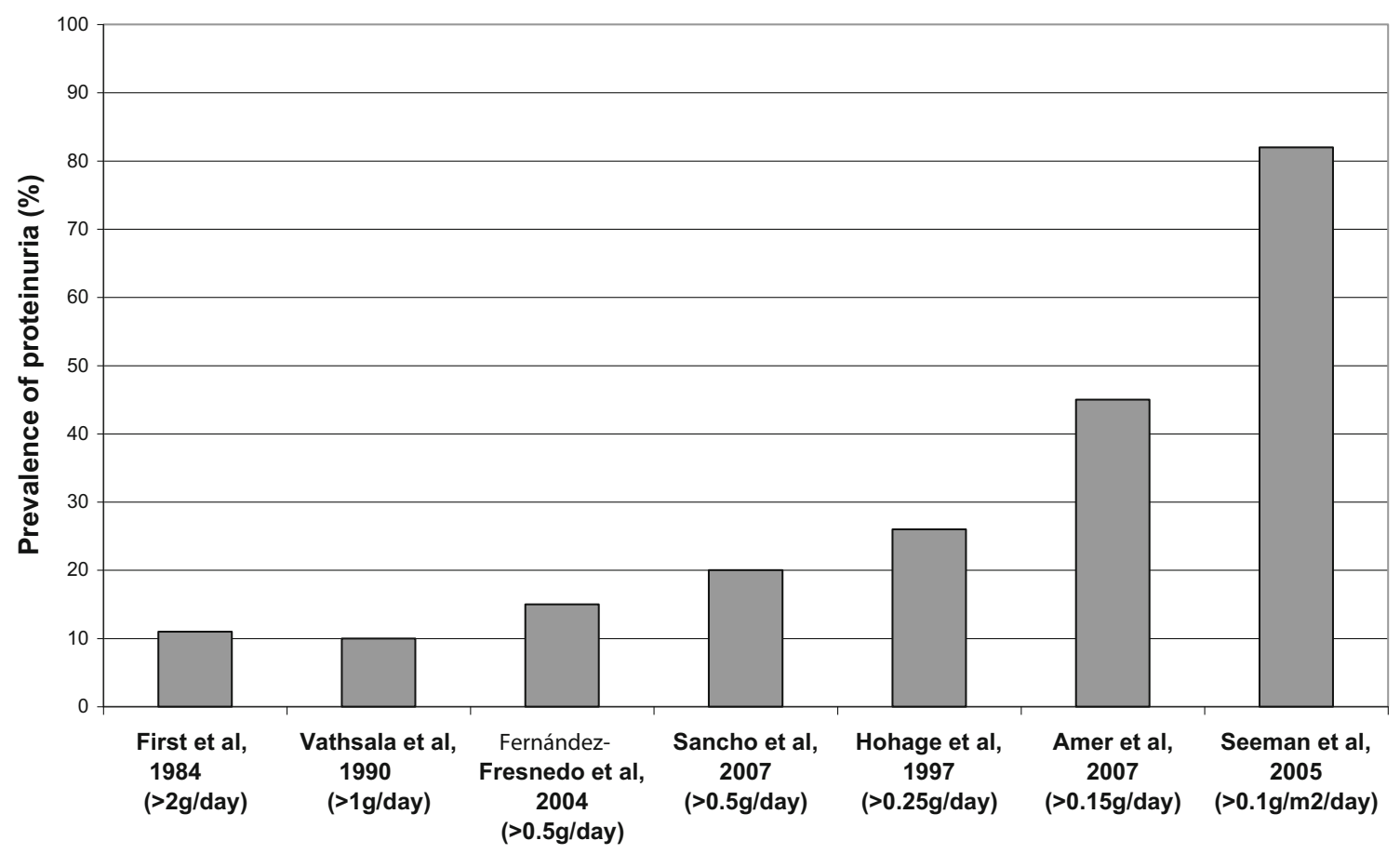

Fig. 1 Prevalence of post-transplant proteinuria according the threshold used for definition of proteinuria 
Table 1 Methods and thresholds for the assessment of proteinuria ${ }^{\mathrm{a}}$

\begin{tabular}{lll}
\hline Parameter & Collection method & Threshold for pathological finding \\
\hline Proteinuria (total) & Spot urine & $>20 \mathrm{mg} / \mathrm{mmol} \mathrm{creatinine,} \mathrm{i.e.}>200 \mathrm{mg} / \mathrm{g} \mathrm{creatinine}$ \\
& & $\begin{array}{c}\text { Nephrotic range: }>220 \mathrm{mg} / \mathrm{mmol} \mathrm{creatinine,} \\
\text { i.e. }>2,200 \mathrm{mg} / \mathrm{g} \mathrm{creatinine}\end{array}$ \\
& 24-h urine collection (children) & $>96 \mathrm{mg} / \mathrm{m}^{2} /$ day \\
& & Nephrotic range: $>960 \mathrm{mg} / \mathrm{m}^{2} / \mathrm{day}$ \\
& 24-h urine collection (adults) & $>150 \mathrm{mg} /$ day \\
Albuminuria & & Nephrotic range: $>2,200 \mathrm{mg} / \mathrm{day}$ \\
Alpha-1-microglobulinuria; & Spot urine & $>3 \mathrm{mg} / \mathrm{mmol} \mathrm{creatinine;} \mathrm{i.e.}>30 \mathrm{mg} / \mathrm{g} \mathrm{creatinine}$ \\
beta-2-microglobulinuria & Spot urine & $>0.55 \mathrm{mg} / \mathrm{mmol} \mathrm{creatinine}$ \\
\hline
\end{tabular}

${ }^{a}$ According to Kidney Disease Improving Global Outcome (KDIGO) guidelines

In the only pediatric study conducted to date on profiling proteinuria, we demonstrated that tubular proteinuria also prevails (79\%) in transplanted children [17]. However, also in our study the presence of glomerular proteinuria signaled in most cases the presence of chronic allograft nephropathy or uncontrolled hypertension.

Tubular as well as glomerular proteinuria is associated with impaired graft survival [22, 23]. Furthermore, both glomerular and tubular proteinuria have the potential to be biomarkers of signal acute rejection as in one study increased albuminuria was detected in patients with clinically relevant acute rejection presenting with decreased glomerular filtration rate (GFR) [24] and alpha-1-microglobulinuria as early as 1-4 days before clinically relevant acute rejection was apparent [25]. However, in one small pediatric study, urinary proteins (albumin or low-molecular-weight proteins) had no predictive value in the detection of acute rejection before clinical symptoms of acute rejection appeared [14]. Therefore, the value of increased proteinuria in predicting acute rejection remains controversial.
In view of the predominance of tubular proteinuria in transplant recipients, proteinuria should be measured in transplanted patients as total proteinuria or both tubular (alpha-1-microglobulin, beta-2-microglobulin) and glomerular (albumin) proteinuria - and not as albuminuria only.

The quantity of proteinuria is usually mild and nonnephrotic. The mean proteinuria in two pediatric studies was only $256 \mathrm{mg} / \mathrm{m}^{2} /$ day and $20 \mathrm{mg} / \mathrm{mmol}$ creatinine $[15,17]$. In another German pediatric study the mean proteinuria was about $200 \mathrm{mg} / \mathrm{m}^{2} /$ day [14]. In adult studies, the degree (quantity) of proteinuria has been found to be associated with allograft glomerular pathology, as biopsy-proven glomerular disease (e.g. transplant glomerulopathy) has been found to be more prevalent in patients with nephrotic-range proteinuria (66-80 \%) than in those with non-nephrotic proteinuria (only $12 \%$ glomerular lesions) $[7,11,23,26]$. The association between the degree of proteinuria and histological pathology is depicted in Fig. 2. Therefore, not only the quality (glomerular, tubular) but also the quantity (degree) of proteinuria is an important marker of the specific type of graft injury.
Fig. 2 Association between the degree of post-transplant proteinuria and histological pathology of the graft

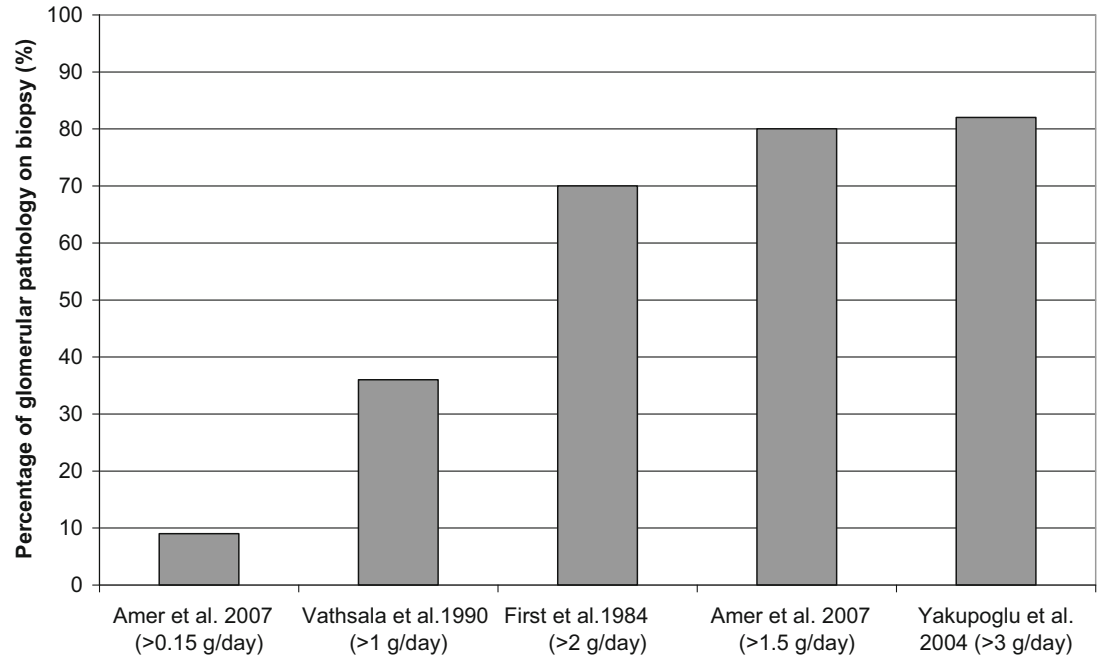


Proteinuria in a patient after RTx may result not only from the graft but also from the residual urine output from the native kidneys. It is of paramount importance to differentiate graft versus native kidney causes of proteinuria, especially in patients with CKD due to idiopathic focal segmental glomerulosclerosis (FSGS) who are at a high risk of recurrence of proteinuria after transplant. Few studies have investigated the early post-transplant evolution of proteinuria. In the largest study on pre-transplant patients with proteinuria conducted to date, Myslak et al. demonstrated that pre-transplant proteinuria strikingly decreases as early as 3 weeks after RTx, from severe nephrotic-range proteinuria (3.6 g/day) to $0.5 \mathrm{~g} /$ day [20]. The only patient in this study with nephrotic-range proteinuria at 3 weeks post-transplant had a recurrence of FSGS. Similar results were obtained in a smaller study by D'Cunha et al., who showed normalization of native kidney proteinuria in $100 \%$ of patients in an average time of 4.5 weeks after RTx [27]. Therefore, persistence of nephrotic-range proteinuria 3-4 weeks post-RTx in a patient with primary native kidney disease FSGS (without bilateral nephrectomy before transplantation) must raise the suspicion of recurrence of the primary renal disease in the graft.

\section{Causes and risk factors for post-transplant proteinuria}

Post-transplant proteinuria can be caused by many factors (Fig. 3), the most common of which are recurrent FSGS, rejection, hypertension and mTOR inhibitors. Determining the cause of proteinuria may be difficult, but is of great importance for the patient because the causal treatment of proteinuria could significantly affect the prognosis of the graft. Therefore, this might be an area in need of further research. In clinical practice the most common cause of post-transplant proteinuria (mainly glomerular type) in a child with idiopathic FSGS is recurrence of FSGS; in a child with acute onset (mainly glomerular type) proteinuria and decreased graft function, it is acute rejection; in a child with mild proteinuria and uncontrolled hypertension, it is the deleterious effect of high blood pressure.

\section{Recurrent or de novo glomerular disease}

Recurrence of FSGS is the most common cause of early and acute onset nephrotic-range proteinuria in patients after RTx [28]. It occurs in $30-40 \%$ of patients with idiopathic FSGS, but is absent in patients with genetically determined FSGS [29]. Proteinuria recurrence occurs usually very early (as early as the first post-transplant day) and is usually of nephrotic range. The detailed management of recurrence of FSGS is beyond the scope of this review and is adequately covered by recent reviews elsewhere [28, 30].

Recurrence of other glomerular diseases (immunoglobulin A nephropathy, membranoproliferative glomerulonephritis) and de novo glomerular diseases in children after transplant are a rare cause of post-transplant proteinuria.

\section{Rejection}

Acute as well chronic rejection [or in older studies chronic allograft nephropathy (CAN)] can cause proteinuria [14, 31, 32]. Many adult studies have shown that a history of previous acute rejection, current acute rejection and chronic rejection are risk factors for post-transplant proteinuria [10, 11, 32]. Also two pediatric studies have shown that children with a history of acute rejection have significantly higher mean proteinuria than children who have never had an episode of rejection (mean proteinuria 416 vs. 107 and 376 vs. $165 \mathrm{mg} / \mathrm{m}^{2} /$ day, respectively) [14, 15] (Fig. 4). Moreover, in one of these studies, proteinuria increased to nearly nephrotic range $\left(960 \mathrm{mg} / \mathrm{m}^{2} /\right.$ day $) 1-2$ days after biopsy-proven acute rejection [14].

Chronic rejection (formerly referred to as CAN) has been also shown to be a risk factor in most adult studies [5-7, 9]. However, one study based on biopsy findings showed a similar proportion of CAN in proteinuric and nonproteinuric adult patients [11]. In two studies conducted by our group in children, CAN was common in those with mainly glomerular proteinuria [17], however total mean proteinuria was not significantly higher in children with biopsy-proven chronic rejection than in those without chronic rejection (147 vs. $263 \mathrm{mg} / \mathrm{m}^{2} /$ day, respectively) [15]. In the former study [17] pathological total proteinuria was also not significantly higher in children with CAN (28\%) than in children without CAN (21\%). However, the patients with CAN had higher albuminuria and had glomerular proteinuria more frequently than children without CAN, showing that CAN manifests predominantly by glomerular proteinuria. Proteinuria was shown to be a significant risk factor for the development of chronic allograft dysfunction in a Polish study on nearly 200 children [33].

Chronic antibody-mediated rejection (CAMR) is an additional risk factor for proteinuria. In a pediatric study by Billing et al. [34], all 20 children with CAMR had proteinuria and $35 \%$ of them had nephrotic-range proteinuria. Based on the results of these studies, transplant glomerulopathy would appear to be a negative prognostic factor for both proteinuria and graft loss.

\section{mTOR inhibitors}

mTOR inhibitors (sirolimus, everolimus) are well-known risk factors for proteinuria [35-37], and therefore all patients after conversion to mTOR inhibitors should have regular 


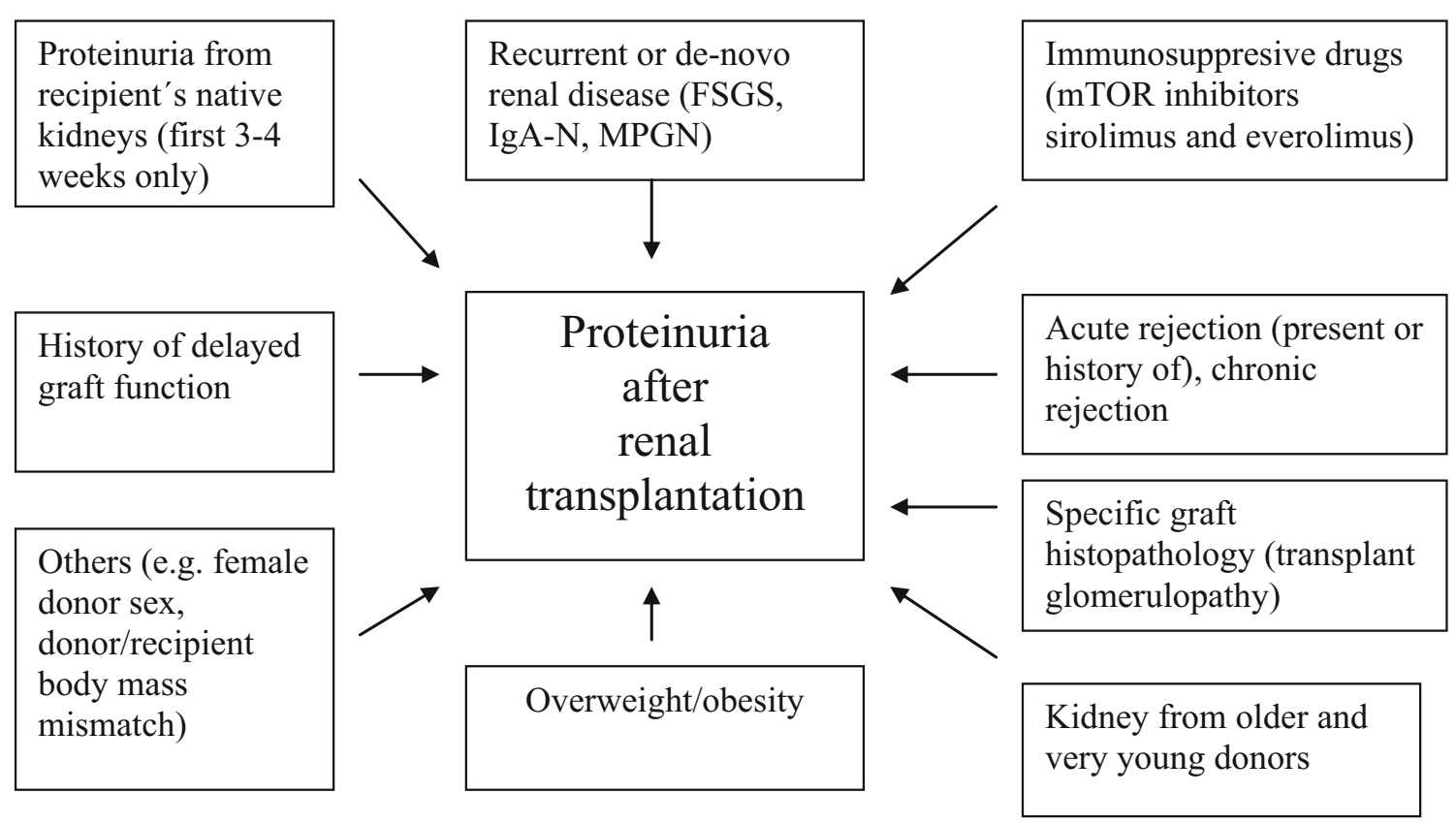

FSGS $=$ focal segmental glomerulosclerosis

IgA-N = IgA nephropathy

MPGN = membranoproliferative glomerulonephritis

Fig. 3 Causes of proteinuria in patients after renal transplantation

proteinuria assessment. Children receiving low-dose everolimus combined with low-dose calcineurin inhibitors have a lower incidence of drug-related proteinuria than patients receiving full-dose sirolimus exposure without calcineurin inhibitors. Proteinuria before conversion to mTOR inhibitors also serves as a predictor of success in conversion from

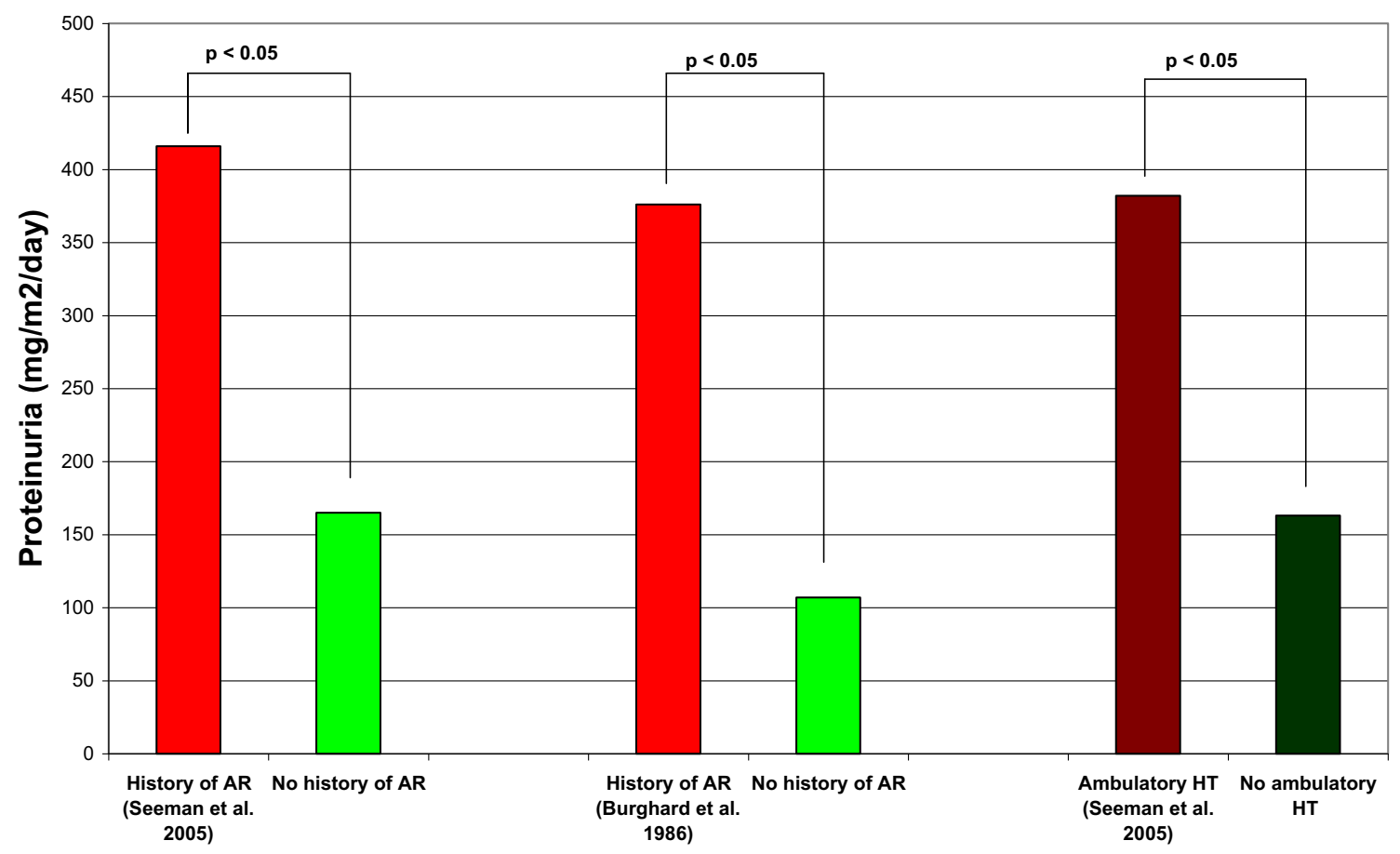

Fig. 4 Proteinuria in transplanted children with/without history of acute rejection $(A R)$ or hypertension $(H T)$ 
calcineurin inhibitor to sirolimus. Diekmann et al. [38] examined the predictors of success in adult patients with chronic allograft dysfunction upon conversion from calcineurin inhibitor to sirolimus and found that those with pre-conversion proteinuria of $>0.8 \mathrm{~g} /$ day had less of a benefit from the conversion than patients with proteinuria of $<0.8 \mathrm{~g} /$ day and that proteinuria of $<0.8 \mathrm{~g} /$ day at conversion was the only independent predictor of positive outcome in conversion.

The mechanism for mTOR inhibitor-induced proteinuria is still under discussion, and various mechanisms have been hypothesized, including antiproliferative and proapoptotic effects on tubular cells or reduction of the expression of nephrin, podocin and other slit diaphragm proteins, leading to reduced podocyte adhesion [37]. No specific histopathology has been observed on graft biopsies in patients with sirolimusassociated proteinuria $[11,39]$.

\section{Hypertension and obesity}

One of the most important and treatable causes of posttransplant proteinuria is hypertension similar to the deleterious effects of hypertension on native CKD [40]. It has been demonstrated in many adult studies that hypertension, or increased blood pressure (BP), is associated with posttransplant proteinuria $[11,15,41]$. Amer et al. found that both systolic and diastolic BP are significantly associated with increasing levels of proteinuria [11].

Hypertension also seems to be a risk factor for proteinuria in the pediatric patient population. Our group found that children with ambulatory hypertension [confirmed by $24-\mathrm{h}$ ambulatory blood pressure monitoring (ABPM)] had significantly higher proteinuria than normotensive children (382 vs. $163 \mathrm{mg} / \mathrm{m}^{2} /$ day, respectively) [15] (Fig. 4). We also reported that children with uncontrolled ambulatory hypertension had twofold higher proteinuria than children with spontaneous normotension or controlled hypertension. Moreover, improved control of ambulatory hypertension with decreased prevalence of uncontrolled hypertension has led to a significant decrease of proteinuria in our 2-year interventional trial [42]. In contrast, children with hypertension defined by office BP only did not have pathological proteinuria more frequently than normotensive children [17]. These results underscore the importance of ABPM in transplanted children.

In adults, obesity and increased body mass index have been shown to be associated with post-transplant proteinuria $[12,43]$. In one pediatric study proteinuria was similar in obese and non-obese children after RTx [44].

\section{Donor factors}

Older and very young donor age ( $>50-60$ years and $<6$ years) and delayed graft function seem to be risk factors for proteinuria [10-12, 43, 45]. To the contrary, the donor source (cadaver vs. living) does not affect the presence of posttransplant proteinuria [43]. No studies to date have tested possible associations between donor factors and proteinuria in transplanted children.

Histopathological findings in transplanted patients with proteinuria

Many studies have investigated the histopathological characteristics in patients with proteinuria after RTx $[5,7,9,11,21,26]$. Transplant glomerulopathy with glomerulonephritis (recurrent or de novo) and chronic vascular rejection are the most common histological findings. The different histological findings in adult proteinuric patients are summarized in Table 2 . The results show that the higher the amount of proteinuria or albuminuria, the higher the prevalence of glomerular pathology of the graft (Table 2, Fig. 2).

In children, no study has performed biopsies primarily due to proteinuria. In our pediatric study on profiling proteinuria, three of five children with glomerular proteinuria had biopsyproven CAN [17].

\section{Clinical consequences of proteinuria in transplant recipients}

Consequences to renal allograft

In adults proteinuria is a strong and independent risk factor for decreased graft survival and a predictor of graft loss. Transplant patients with proteinuria show shorter graft survival than those without proteinuria [4, 6-12] (Table 3; Fig. 5). The most robust evidence comes from the results of the large nationwide Spanish study on 3,365 patients [10], which showed that proteinuria at 1-year after RTx is an excellent marker of poor long-term allograft prognosis.

The association between proteinuria and graft survival is linear, i.e. the higher the amount of proteinuria, the lower the graft survival. Adults with proteinuria of $>3 \mathrm{~g}$ /day have a 2.5fold higher risk of graft loss than patients with proteinuria of $0.5-1.5 \mathrm{~g} /$ day, fivefold higher risk than patients with proteinuria of $0.150-0.5 \mathrm{~g} /$ day and 19-fold higher risk than patients with proteinuria of $<0.150 \mathrm{~g} /$ day [39]. Furthermore, the association between proteinuria and graft survival is independent of the glomerular pathological state found on graft biopsy and baseline GFR $[9,11]$. The inverse relationship between proteinuria and graft survival is obvious even in patients with low proteinuria levels, such as $0.150-0.2 \mathrm{~g} /$ day $[11,13]$. This relationship is evident not only 1 -year post-transplant $[4,10$, $11,13]$, but also as early as 3 months after RTx $[46,47]$ 
(Table 3). Therefore, persistent proteinuria due to pathological causes at any level, starting with $0.150 \mathrm{~g} / \mathrm{day}$, and at any time post-transplant, starting 3 months after RTx, is clearly associated with decreased graft survival in adults.

Despite these findings of a clear association between proteinuria and graft survival, it is still a matter of debate whether post-transplant proteinuria is a real cause of graft loss or only the result of the primary pathology (e.g. recurrence of FSGS, acute and chronic rejection, hypertension, etc.), or both $[18,48-50]$. The mechanisms by which proteinuria may induce renal injury include: (1) the release of fibrosis-promoting factors from renal cells activated by the proteinuria, resulting in interstitial fibrosis; (2) the uptake of urinary proteins from proximal tubular cells, triggering an increased production of angiotensin II, endothelin, cytokines, chemoattractants and transcriptional factors that promote lymphocyte and monocyte recruitment with transdifferentiation of tubular epithelial cells into fibroblasts, leading to scarring [18, 43, 48-53]. Moreover, many studies using multivariate analysis have shown that proteinuria is an independent risk factor for graft loss after adjustment for other possible causes, such as rejection or hypertension $[4,10,46]$.

In children with chronic nephropathies of native kidneys, proteinuria is, together with hypertension, a well-established risk factor for progression [1, 2, 54]. Moreover, reduction of proteinuria with angiotensin-converting enzyme inhibitors (ACEIs) is associated with slower progression of chronic renal insufficiency [54].

In transplanted children, no study has been published dealing with the association between proteinuria and graft survival, and the data from pediatric studies dealing with the recurrence of proteinuria in patients with idiopathic FSGS and its impact on graft survival are conflicting. Some studies showed an impaired graft survival in FSGS patients [29, 55], whereas others did not find any differences in graft survival between recurrent FSGS patients and non-FSGS children [56, 57]. Unpublished data from a retrospective study conducted in our transplantation center show that children (without recurrent FSGS) with pathological proteinuria at 1-year post-transplant have significantly worse long-term graft survival than those with normal proteinuria at 1-year post transplant. Therefore, it seems that proteinuria is associated with worse graft survival not only in adults but also in children.

\section{Consequences to the patients}

Similar to the general adult population, proteinuria is also, together with hypertension, associated with increased patient mortality in the population of transplanted patients [4, 10]. Adult proteinuric patients have a lower patient survival than 


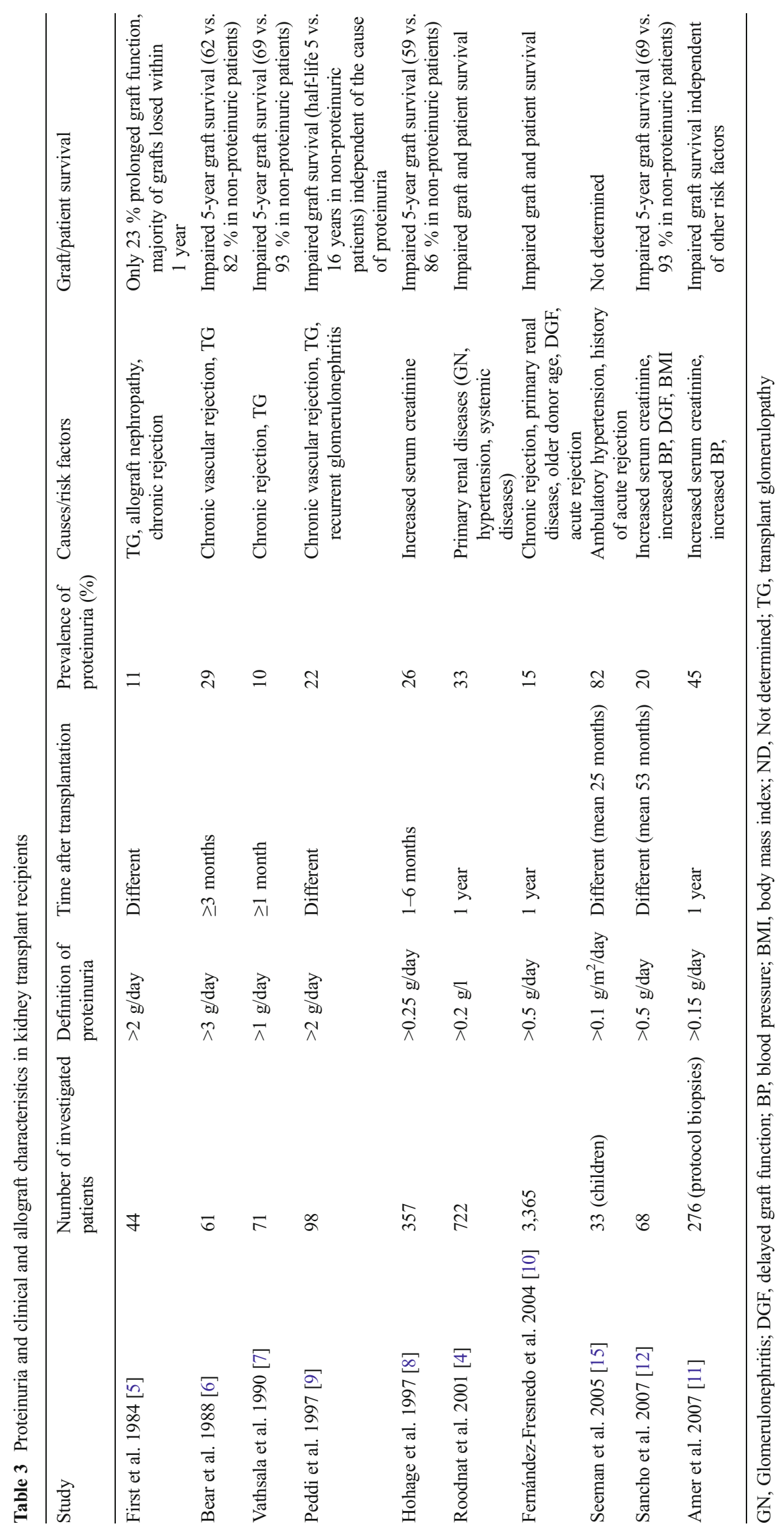




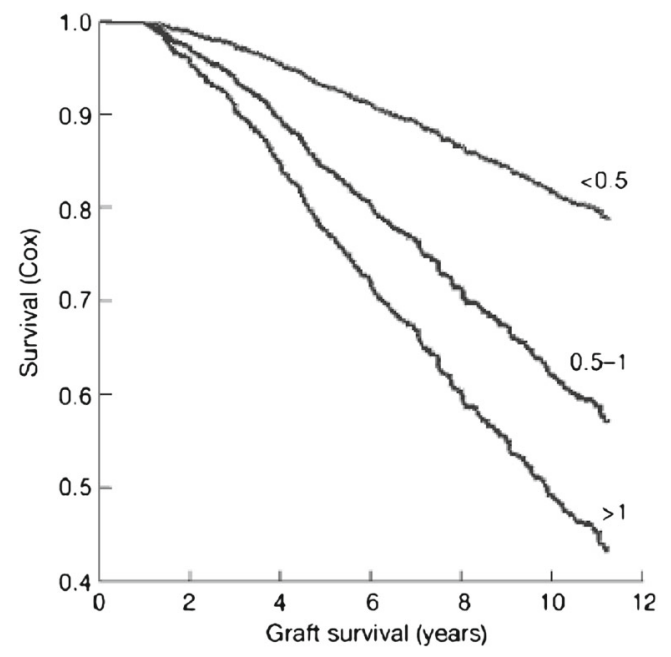

Fig. 5 Graft survival according to 1-year proteinuria in adult kidney transplant recipients (from Fernández-Fresnedo et al. 2004 [10], reproduced with permission)

non-proteinuric patients. Similar studies in children are lacking, and this area could be of interest for further research.

\section{Diagnostics of post-transplant proteinuria}

How should proteinuria be measured in transplanted children?

Both total proteinuria and albuminuria should be measured in transplanted patients to determine the total amount and glomerular type of proteinuria. To assess the tubular type of proteinuria, i.e. the predominant type of proteinuria in transplanted patients, either tubular proteins (e.g. alpha-1microglobulin, beta-2-microglobulin) should be measured simultaneously or the non-albumin proteinuria (i.e. tubular, non-glomerular) should be calculated from total proteinuria and albuminuria (non-albumin proteinuria $=$ total proteinuria minus albuminuria) [23].

Proteinuria and albuminuria should be preferably measured as the protein (albumin)/creatinine ratio. The same thresholds suggested by the Kidney Disease Improving Global Outcomes (KDIGO) for the definition of pathological proteinuria as for non-transplant patients should be used in transplanted children (Table 1).

How frequently should proteinuria be measured?

The current 2009 KDIGO clinical practice guideline on the care of adult transplant recipients [58] suggests measuring proteinuria at least once within the first month after RTx, at least every 3 months between months 1 and 12, and at least annually $\geq 1$ year post transplant. A similar minimal frequency should also be used for screening proteinuria measurements in transplanted children. Patients with proteinuria should be measured more frequently (every 1-3 months) to monitor the changes in proteinuria.

The most recent 2012 KDIGO clinical practice guideline for the evaluation and management of CKD newly includes proteinuria (as part of the cause), GFR and albuminuria (proteinuria) criteria for the purpose of CKD risk stratification/staging [19]. The consensus stated that the cause of disease is included because of the fundamental importance in predicting the outcome of CKD and choice of cause-specific treatments. This new staging system is fully applicable to pediatric patients. However, in these guidelines there are many gaps in the assessment, timing and quality for various pediatric-specific proteinuria measures, not to mention pediatric transplant-specific recommendations. There is a need for future research to provide evidence for appropriate evidence-based thresholds for transplant proteinuria, especially in pediatric patients.

Special care must be taken in patients with idiopathic (non-genetic) FSGS who have a 30-40\% risk of recurrence of proteinuria/FSGS. In these patients proteinuria should be measured daily in the first $2-3$ weeks postRTx to detect and treat possible recurrence as early as possible. Thereafter, proteinuria should be measured at every outpatient visit during the first year post-RTx as the recurrence can also occur later.

What is the cause of proteinuria?

All efforts must be made to reveal the cause of post-transplant proteinuria (e.g. recurrence, rejection, hypertension). Renal graft biopsy is not necessary to diagnose recurrence of disease in a child with idiopathic FSGS who has acute onset nephrotic-range proteinuria. On the contrary, biopsy should be performed in unexplained persistent proteinuria (duration $>3$ months), especially in new-onset proteinuria, acute deterioration of proteinuria or unexplained nephrotic-range proteinuria, as these patients always show graft-specific pathological findings, such as de novo glomerulonephritis, transplant glomerulopathy or chronic rejection [20].

The diagnostic algorithm for proteinuria in transplanted children is given in Fig. 6.

\section{Treatment of post-transplant proteinuria}

The treatment of post-transplant proteinuria should be started early after its diagnosis, should be especially focused on persistent proteinuria (duration $>3$ months) of any pathological range (even low levels of $>0.150 \mathrm{~g} /$ day) and on unexplained nephrotic-range proteinuria of any duration. The 
Fig. 6 Diagnostic algorithm for a transplanted child with proteinuria. $B P$ Blood pressure, $A B P M$ ambulatory blood pressure monitoring, $H T$ hypertension, $T x$ transplantation, FSGS focal segmental glomerulosclerosis

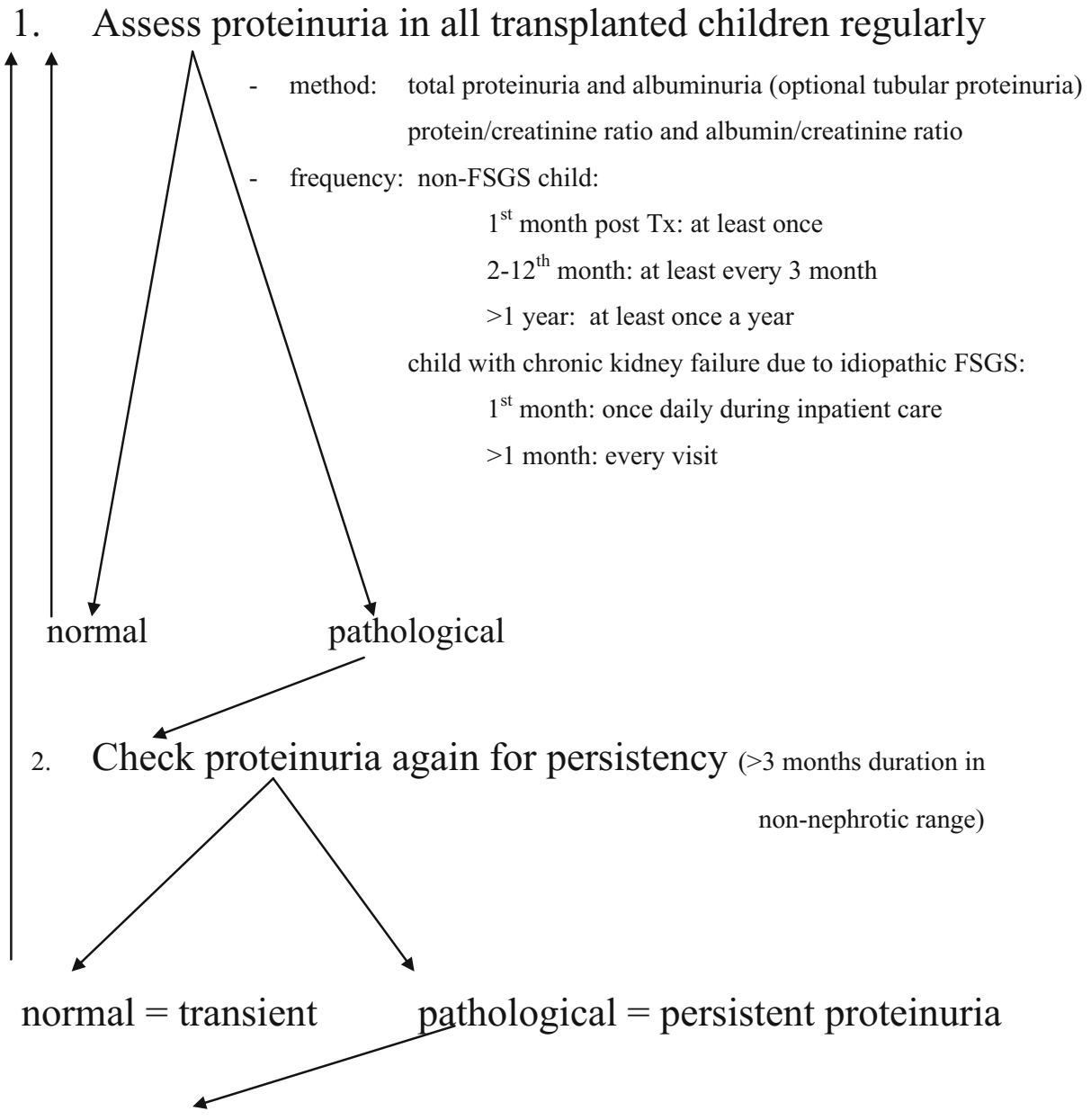

3. Identify the cause of proteinuria

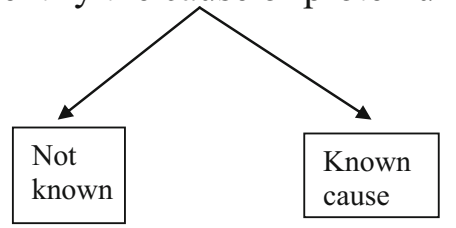

Consider graft biopsy, especially recurrence of FSGS (graft biopsy not necessary) rejection (biopsy) mTOR inhibitors hypertension (clinic BP and ABPM for nocturnal HT) other causes and risk factors

4. Consider graft biopsy, especially if: new onset proteinuria, deterioration of previous mild proteinuria or nephrotic-range proteinuria treatment should be causal whenever possible and symptomatic if the precise cause could not be identified.

\section{Causal treatment}

The primary cause must be treated if it has been identified (e.g. recurrence, rejection, hypertension). The precise recommendations for the treatment of these causes of proteinuria are beyond the scope of this review article and are covered comprehensively elsewhere $[28,56,57,59]$.
Symptomatic non-specific antiproteinuric treatment with ACEIs/ARBs

Angiotensin-converting enzyme inhibitors and angiotensin receptor blockers (ARBs) can decrease proteinuria not only in adults but also in pediatric renal transplant recipients $[60,61]$. Ramipril reduces proteinuria in nearly all proteinuric children even without influencing the BP [61]. Therefore, ACEIs/ARBs should also be used in normotensive patients with proteinuria. These drugs are also 
recommended by the recent KDIGO guidelines on hypertension in CKD [62].

The recommended doses should be similar to those administered to non-transplanted children (Table 4). Combination ACEI/ARB therapy was found to further reduce proteinuria by $30-40 \%$ in non-transplanted children already on maximal doses of ACEIs [63]. This combination is also possible in transplanted patients [17], but caution must then be taken due to the increased risk of hyperkalemia or acute deterioration of the GFR, especially if the child is dehydrated. The mechanisms of the antiproteinuric effects of ACEI/ARB therapy are various, with the main ones being long-term reduction of systemic and intraglomerular pressure (hemodynamic mechanisms) and antiproliferative and antifibrotic effects or preservation of the podocyte slit diaphragm structure (non-hemodynamic mechanisms) [64].

BP-lowering therapy by non-ACEI/non-ARB antihypertensive drugs and vitamin $\mathrm{D}$ analogs

In children with persistent proteinuria despite ACEI/ARB therapy, other antihypertensive drugs that are allowed in children (calcium channel blockers, especially non-dihydropyridine, beta-blockers, diuretics) should be added to achieve the recommended target BP of $<75$ th percentile. This recommendation is based on current KDIGO guidelines for adult transplant patients [58], expert opinion [39] and on the European Society for Hypertension guidelines for non-transplanted CKD children [65]. However, it should be noted that no study in adult or children has ever shown a benefit of these BP targets in transplanted patients.

Antiproteinuric effects of non-ACEI/ARB antihypertensive drugs have also been demonstrated in pediatric transplant patients with proteinuria, in whom proteinuria decreased after a reduction of BP using only non-ACEI/ARB drugs [66].
Several studies have showed that vitamin D analogs may further reduce proteinuria in CKD patients, including renal transplant recipients with residual proteinuria, in addition to current treatment regimens with $\mathrm{ACEI} / \mathrm{ARB} /$ other antihypertensive drugs [67]. However, as no studies in pediatric transplant patients have been published to date, no recommendation can be given for transplanted children.

What is the target proteinuria in transplanted children?

There are no published recommended targets for transplanted patients. However, taking into account the evidence that even low levels of proteinuria $(0.150-0.2 \mathrm{~g} /$ day $)$ is a risk factor for graft loss in adults $[13,39]$, that pediatric patients with proteinuria of $>30 \mathrm{mg} / \mathrm{mmol}$ creatinine have worse graft survival than children without this level of proteinuria and that the threshold for normal proteinuria according the recent KDIGO guidelines is $<20 \mathrm{mg} / \mathrm{mmol}$ creatinine, adoption of the latter target would seem logical.

The treatment algorithm for proteinuria in transplanted children is given in Fig. 7.

Can decreased proteinuria improve graft survival?

There is no prospective interventional study showing that antiproteinuric therapy results in improved graft survival. However, three indices speak for a renoprotective effect of antiproteinuric treatment in transplanted patients. The first is an independent association between proteinuria and graft survival from observational studies (Table 3); the second is a retrospective adult study by Halimi et al., which showed that treatment-induced reduction of proteinuria is associated with decreased long-term graft loss independently of initial proteinuria [46]. Lastly, the pediatric ESCAPE trial showed that a decrease in proteinuria is a significant independent predictor of delayed progression of native CKD [54].

Table 4 Recommended doses for angiotensin-converting enzyme inhibitors and angiotensin receptor blockers in children

\begin{tabular}{|c|c|c|c|}
\hline Class of drugs & Generic name & $\begin{array}{l}\text { Recommended daily dose }(\mathrm{mg} / \mathrm{kg} / \text { day, if not } \\
\text { indicated otherwise) }\end{array}$ & $\begin{array}{l}\text { Number of } \\
\text { daily doses }\end{array}$ \\
\hline \multirow[t]{4}{*}{ Angiotensin-converting enzyme inhibitors } & Enalapril $^{\mathrm{a}}$ & $0.08-0.6$ & $2 \times$ \\
\hline & Ramipril $^{\mathrm{a}}$ & $1.5-6\left(\mathrm{mg} / \mathrm{m}^{2} /\right.$ day $)$ & $1 \times$ \\
\hline & Fosinopril & $0.1-0.6$ & $1 \times$ \\
\hline & Lisinopril & $0.08-0.6$ & $1 \times$ \\
\hline \multirow[t]{4}{*}{ Angiotensin receptor blockers } & Losartan $^{\mathrm{a}}$ & $0.7-1.4$ & $1 \times$ \\
\hline & Irbesartan $^{\mathrm{a}}$ & $\begin{array}{l}6-12 \text { years of age: } 75-150 \mathrm{mg} / \text { day; } \geq 13 \text { years } \\
\text { of age: } 150-300 \mathrm{mg} / \text { day }\end{array}$ & $1 \times$ \\
\hline & Valsartan & $1-2$ & $1 \times$ \\
\hline & Candesartan $^{\mathrm{a}}$ & $0.16-0.5$ & $1 \times$ \\
\hline
\end{tabular}

${ }^{a}$ Drugs used in the clinical setting in children after renal transplantation, based on published studies 
Fig. 7 Treatment algorithm for a transplanted child with persistent proteinuria. $A C E I$ angiotensinconverting enzyme inhibitor, $A R B$ angiotensin II receptor blockers, $C C B$ calcium channel blockers, GFR glomerular filtration rate, FSGS focal segmental glomerulosclerosis

\section{Cause of persistent proteinuria ( $>3$ months)}
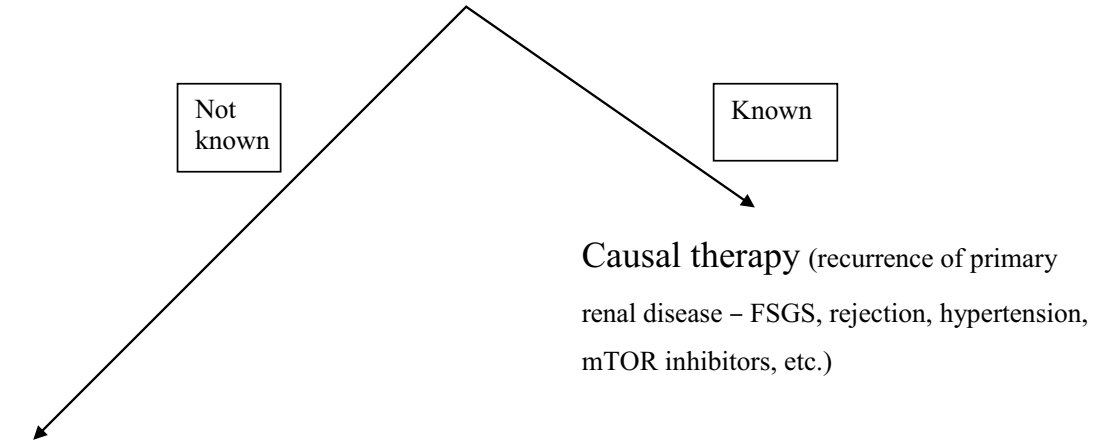

2. Add ACEI or ARB (also in a normotensive child) in submaximal dose<smiles>C1CC1</smiles>

Increase $\mathrm{ACEI}$ or $\mathrm{ARB}$ to maximal dose if proteinuria persists

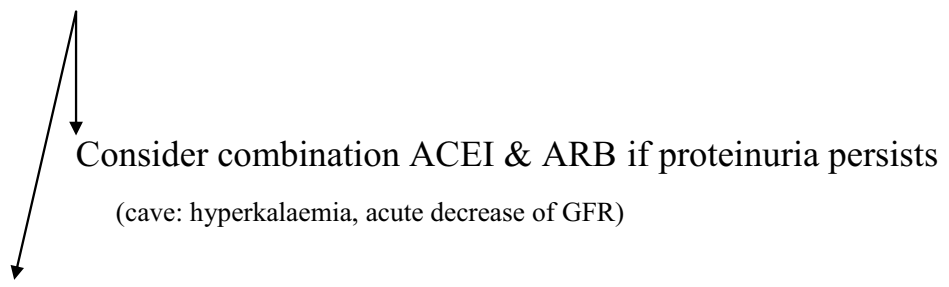

3. Add other antihypertensive drug (non-dihydropyridine CCB, diuretics, beta-blockers) to achieve target $\mathrm{BP}<75^{\text {th }}$ percentile

Consider active vitamin D therapy in a vitamin D deficient child

Target (total) proteinuria should be $\leq 20 \mathrm{mg} / \mathrm{mmol}$ creatinine

\section{Conclusions}

Proteinuria is a frequent complication in children after $\mathrm{RTx}$, with a prevalence ranging from 40 to $80 \%$. It is usually mild and of predominantly tubular in origin; however, the glomerular type of proteinuria prevails in patients with higher amounts of proteinuria. The most common etiologies and risk factors are recurrent FSGS, rejection, mTOR inhibitors and hypertension. Post-transplant proteinuria is, independently of its cause, associated with worse graft survival. Therefore, it is a useful prognostic marker for graft survival beyond that provided by graft histopathology, graft function or BP. Proteinuria should be measured routinely in all transplanted children to diagnose it early and enable appropriate treatment.

Treatment of post-transplant proteinuria should be focused primarily on the cause. Symptomatic antiproteinuric therapy consists of ACEI/ARBs, but other antihypertensive drugs should be added to the therapeutic regimen to reach the target BP of $<75$ th percentile. Target proteinuria should be as normal as possible with a suggested threshold of $<20 \mathrm{mg} / \mathrm{mmol}$ creatinine.

Further prospective interventional studies are needed to answer the open question of whether antiproteinuric therapy can delay the progression of chronic allograft dysfunction, thereby improving the long-term graft survival in kidney transplant recipients.

\section{Key summary points}

1. Proteinuria is common in children after RTx (40-80\%).

2. The main causes and risk factors for post-transplant proteinuria are recurrent FSGS, rejection, hypertension and mTOR inhibitors. 
3. Proteinuria has a deleterious effect on graft survival in adults and probably also in pediatric patients after renal transplantation.

4. Proteinuria should be regularly measured in all transplanted patients.

5. Treatment of post-transplant proteinuria should be focused on the cause-if unknown, non-specific antiproteinuric ACEI/ARB therapy should be initiated and $\mathrm{BP}$ targeted to $<75$ th percentile.

\section{Multiple choice questions (only one correct answer- answers are provided following the Reference list)}

1. How frequent is proteinuria in children after renal transplantation:
a. $5-10 \%$
b. $10-20 \%$
c. $20-40 \%$
d. $40-80 \%$

2. What is the recommended method for assessment of proteinuria in transplanted children?
a. Albuminuria alone
b. Total proteinuria and alpha-1-microglobulinuria
c. Alpha-1-microglobulinuria alone
d. Total proteinuria and albuminuria

3. The main causes of persistent post-transplant proteinuria are:
a. Proteinuria from the diseased native kidneys
b. mTOR inhibitors and calcineurin inhibitors
c. Recurrence of FSGS, hypertension and rejection
d. Older donor age and delayed graft function

4. The consequences of proteinuria after transplantation are:
a. Hyperfiltration
b. Impaired graft function and survival
c. Edema and hypertension
d. Hypotension

5. Angiotensin receptor blockers can further decrease proteinuria in children already treated with angiotensin-converting enzyme inhibitors by:
a. $10-20 \%$
b. $20-30 \%$
c. $30-40 \%$
d. $40-60 \%$

Acknowledgments Supported by the Ministry of Health, Czech Republic - Conceptual Development of Research Organization, University Hospital Motol, Prague, Czech Republic 00064203 and by the project ED2.1.00/03.0076 from the European Regional Development Fund.

\section{References}

1. Wingen AM, Fabian-Bach C, Schaefer F, Mehls O (1997) Randomised multicentre study of a low-protein diet on the progression of chronic renal failure in children. European Study Group of Nutritional Treatment of Chronic Renal Failure in Childhood Lancet 349:1117-1123

2. Wong CS, Pierce CB, Cole SR, Warady BA, Mak RH, Benador NM, Kaskel F, Furth SL, Schwartz GJ, CKiD Investigators (2009) Association of proteinuria with race, cause of chronic kidney disease, and glomerular filtration rate in the chronic kidney disease in children study. Clin J Am Soc Nephrol 4:812-819

3. Cravedi P, Ruggenenti P, Remuzzi G (2012) Proteinuria should be used as a surrogate in CKD. Nat Rev Nephrol 8:301-306

4. Roodnat JI, Mulder PG, Rischen-Vos J, van Riemsdijk IC, van Gelder T, Zietse R, IJzermans JN, Weimar W (2001) Proteinuria after renal transplantation affects not only graft survival but also patient survival. Transplantation 72:438-444

5. First MR, Vaidya PN, Maryniak RK, Weiss MA, Munda R, Fidler JP, Penn I, Alexander JW (1984) Proteinuria following transplantation. Correlation with histopathology and outcome Transplantation 38: 607-612

6. Bear RA, Aprile M, Sweet J, Cole EH (1988) Proteinuria in renal transplant recipients: incidence, cause, prognostic importance. Transplant Proc 20:1235-1236

7. Vathsala A, Verani R, Schoenberg L, Lewis RM, Van Buren CT, Kerman RH, Kahan BD (1990) Proteinuria in cyclosporine-treated renal transplant recipients. Transplantation 49:35-41

8. Hohage H, Kleyer U, Brückner D, August C, Zidek W, Spieker C (1997) Influence of proteinuria on long-term transplant survival in kidney transplant recipients. Nephron 75:160-165

9. Peddi VR, Dean DE, Hariharan S, Cavallo T, Schroeder TJ, First MR (1997) Proteinuria following renal transplantation: correlation with histopathology and outcome. Transplant Proc 29:101-103

10. Fernández-Fresnedo G, Plaza JJ, Sánchez-Plumed J, Sanz-Guajardo A, Palomar-Fontanet R, Arias M (2004) Proteinuria: a new marker of long-term graft and patient survival in kidney transplantation. Nephrol Dial Transplant [Suppl 3]:iii47-51

11. Amer H, Fidler ME, Myslak M, Morales P, Kremers WK, Larson TS, Stegall MD, Cosio FG (2007) Proteinuria after kidney transplantation, relationship to allograft histology and survival. Am J Transplant 7:2748-2756

12. Sancho A, Gavela E, Avila A, Morales A, Fernández-Nájera JE, Crespo JF, Pallardo LM (2007) Risk factors and prognosis for proteinuria in renal transplant recipients. Transplant Proc 39:2145-2147

13. Kang NR, Lee JE, Huh W, Kim SJ, Kim YG, Kim DJ, Oh HY (2009) Minimal proteinuria one year after transplant is a risk factor for graft survival in kidney transplantation. J Korean Med Sci 24[Suppl]: S129-134

14. Burghard R, Galaske RG, Offner G, Ehrich JH, Leititis JU, Brodehl J (1986) Urinary protein analysis in the early detection of acute rejection episodes after renal transplantation in children. Clin Nephrol 26: $1-6$

15. Seeman T, Simkova E, Kreisinger K, Vondrak K, Dusek J, Dvorak P, Janda J (2005) Proteinuria in children after renal transplantation. Transplant Proc 37:4282-4283

16. Chua AN, Alexander SR, Sarwal MM, Millan M, Salvatierr O Jr, Yorgin PD (2006) Proteinuria in pediatric renal transplant recipients during the first 60 post-transplant days. Pediatr Transplant 10:957961

17. Seeman T, Dusek J, Vondrak K, Spatenka J, Feber J (2009) Profiling proteinuria in children after renal transplantation. Pediatr Nephrol 24: 2439-2444

18. Hogg RJ, Portman RJ, Milliner D, Lemley KV, Eddy A, Ingelfinger J (2000) Evaluation and management of Proteinuria and nephrotic 
syndrome in children: recommendations from a pediatric nephrology panel established at the National Kidney Foundation conference on proteinuria, albuminuria, risk, assessment, detection, and elimination (PARADE). Pediatrics 105:1242-1249

19. Kidney Disease: Improving Global Outcome (KDIGO) (2013) KDIGO 2012 clinical practice guideline for the evaluation and management of chronic kidney disease. Kidney Int Suppl 3:S1-150

20. Myslak M, Amer H, Morales P, Fidler ME, Gloor JM, Larson TS, Stegall MD, Cosio FG (2006) Interpreting post-transplant proteinuria in patients with proteinuria pre-transplant. Am J Transplant 6:1660-1665

21. Schaub S, Mayr M, Hönger G, Bestland J, Steiger J, Regeniter A, Mihatsch MJ, Wilkins JA, Rush D, Nickerson P (2007) Detection of subclinical tubular injury after renal transplantation: comparison of urine protein analysis with allograft histopathology. Transplantation 84:104-112

22. Teppo AM, Honkanen E, Finne P, Törnroth T, Grönhagen-Riska C (2004) Increased urinary excretion of alpha1-microglobulin at 6 months after transplantation is associated with urinary excretion of transforming growth factor-betal and indicates poor long-term renal outcome. Transplantation 78:719-724

23. Halimi JM, Matthias B, Al-Najjar A, Laouad I, Chatelet V, Marlière JF, Nivet H, Lebranchu Y (2007) Respective predictive role of urinary albumin excretion and nonalbumin proteinuria on graft loss and death in renal transplant recipients. Am J Transplant 7:27752781

24. Woo J, Floyd M, Cannon DC (1981) Albumin and beta 2microglobulin radioimmunoassays applied to monitoring of renalallograft function and in differentiating glomerular and tubular diseases. Clin Chem 27:709-713

25. Teppo AM, Honkanen E, Ahonen J, Grönhagen-Riska C (2000) Changes of urinary alpha1-microglobulin in the assessment of prognosis in renal transplant recipients. Transplantation 70:1154-1159

26. Yakupoglu U, Baranowska-Daca E, Rosen D, Barrios R, Suki WN, Truong LD (2004) Post-transplant nephrotic syndrome: a comprehensive clinicopathologic study. Kidney Int 65:2360-2370

27. D'Cunha PT, Parasuraman R, Venkat KK (2005) Rapid resolution of proteinuria of native kidney origin following live donor renal transplantation. Am J Transplant 5:351-355

28. Ponticelli C (2010) Recurrence of focal segmental glomerular sclerosis (FSGS) after renal transplantation. Nephrol Dial Transplant 25: 25-31

29. Jungraithmayr TC, Hofer K, Cochat P, Chernin G, Cortina G, Fargue S, Grimm P, Knueppel T, Kowarsch A, Neuhaus T, Pagel P, Pfeiffer KP, Schäfer F, Schönermarck U, Seeman T, Toenshoff B, Weber S, Winn MP, Zschocke J, Zimmerhackl LB (2011) Screening for NPHS2 mutations may help predict FSGS recurrence after transplantation. J Am Soc Nephrol 22:579-585

30. Hickson LJ, Gera M, Amer H, Iqbal CW, Moore TB, Milliner DS, Cosio FG, Larson TS, Stegall MD, Ishitani MB, Gloor JM, Griffin MD (2009) Kidney transplantation for primary focal segmental glomerulosclerosis: outcomes and response to therapy for recurrence. Transplantation 87:1232-1239

31. Câmara NO, Silva MS, Nishida S, Pereira AB, Pacheco-Silva A (2004) Proximal tubular dysfunction is associated with chronic allograft nephropathy and decreased long-term renal-graft survival. Transplantation 78:269-275

32. Djamali A, Samaniego M, Torrealba J, Pirsch J, Muth BL (2010) Increase in proteinuria $>200 \mathrm{mg} / \mathrm{g}$ after late rejection is associated with poor graft survival. Nephrol Dial Transplant 25:1300-1306

33. Grenda R (2000) Factors influencing the development of chronic renal allograft nephropathy in children. Pol Merkur Lekarski 8:282283

34. Billing H, Rieger S, Süsal C, Waldherr R, Opelz G, Wühl E, Tönshoff B (2012) IVIG and rituximab for treatment of chronic antibodymediated rejection: a prospective study in paediatric renal transplantation with a 2-year follow-up. Transpl Int 25:1165-1173
35. van den Akker JM, Wetzels JF, Hoitsma AJ (2006) Proteinuria following conversion from azathioprine to sirolimus in renal transplant recipients. Kidney Int 70:1355-1357

36. Butani L (2004) Investigation of pediatric renal transplant recipients with heavy proteinuria after sirolimus rescue. Transplantation 78: $1362-1366$

37. Diekmann F, Andrés A, Oppenheimer F (2012) mTOR inhibitorassociated proteinuria in kidney transplant recipients. Transplant Rev 26:27-29

38. Diekmann F, Budde K, Oppenheimer F, Fritsche L, Neumayer HH, Campistol JM (2004) Predictors of success in conversion from calcineurin inhibitor to sirolimus in chronic allograft dysfunction. Am J Transplant 4:1869-1875

39. Amer H, Cosio FG (2009) Significance and management of proteinuria in kidney transplant recipients. J Am Soc Nephrol 20:2490-2492

40. Knoll GA (2009) Proteinuria in kidney transplant recipients: prevalence, prognosis, and evidence-based management. Am J Kidney Dis 54:1131-1144

41. Calviño J, Lens XM, Romero R, Sánchez-Guisande D (2000) Longterm anti-proteinuric effect of Losartan in renal transplant recipients treated for hypertension. Nephrol Dial Transplant 15:82-86

42. Seeman T, Šimková E, Kreisinger J, Vondrák K, Dušek J, Gilík J, Dvořák P, Janda J (2007) Improved control of hypertension in children after renal transplantation: results of a two-yr interventional trial. Pediatr Transplant 11:491-497

43. Suárez Fernández ML, G-Cosío F (2011) Causes and consequences of proteinuria following kidney transplantation. Nefrologia 31:404 414

44. Kasap B, Soylu A, Türkmen M, Kavukçu S, Bora S, Gülay H (2006) Effect of obesity and overweight on cyclosporine blood levels and renal functions in renal adolescent recipients. Transplant Proc 38: 463-465

45. Fontán MP, Rodriguez-Carmon A, Falcón TG, Valdés F (1999) Early proteinuria in renal transplant recipients treated with cyclosporin. Transplantation 67:561-568

46. Halimi JM, Laouad I, Buchler M, Al-Najjar A, Chatelet V, Houssaini TS, Nivet H, Lebranchu Y (2005) Early low-grade proteinuria: causes, short-term evolution and long-term consequences in renal transplantation. Am J Transplant 5:2281-2288

47. Cherukuri A, Welberry-Smith MP, Tattersall JE, Ahmad N, Newstead CG, Lewington AJ, Baker RJ (2010) The clinical significance of early proteinuria after renal transplantation. Transplantation 89:200-207

48. Halimi J, Laouad I, Buchler M, Al-Najjar A, Chatelet V, Houssaini TS, Nivet H, Lebranchu Y (2006) Early proteinuria is a strong indicator of donor renal lesions, ischemia-reperfusion injury and immunological aggression. Transplant Proc 38:2319-2320

49. Reichel H, Zeier M, Ritz E (2004) Proteinuria after renal transplantation: pathogenesis and management. Nephrol Dial Transplant 19: 301-305

50. Ponticelli C, Graziani G (2012) Proteinuria after kidney transplantation. Transpl Int 25:909-917

51. Burton C, Harris KP (1996) The role of proteinuria in the progression of chronic renal failure. Am J Kidney Dis 27:765-775

52. Abate M, Zoja C, Remuzzi G (2006) How does proteinuria cause progressive renal damage? J Am Soc Nephrol 17:2974-2984

53. Donadelli R, Zanchi C, Morigi M, Buelli S, Batani C, Tomasoni S, Corna D, Rottoli D, Benigni A, Abbate M, Remuzzi G, Zoja C (2003) Protein overload induces fractalkine upregulation in proximal tubular cells through nuclear factor kappaB- and p38 mitogenactivated protein kinase-dependent pathways. J Am Soc Nephrol 14:2436-2446

54. Wühl E, Trivelli A, Picca S, Litwin M, Peco-Antic A, Zurowska A, Testa S, Jankauskiene A, Emre S, Caldas-Afonso A, Anarat A, Niaudet P, Mir S, Bakkaloglu A, Enke B, Montini G, Wingen AM, Sallay P, Jeck N, Berg U, Caliskan S, Wygoda S, HohbachHohenfellner K, Dusek J, Urasinski T, Arbeiter K, Neuhaus T, 
Gellermann J, Drozdz D, Fischbach M, Möller K, Wigger M, Peruzzi L, Mehls O, Schaefer F; ESCAPE Trial Group (2009) Strict bloodpressure control and progression of renal failure in children. $\mathrm{N}$ Engl $\mathrm{J}$ Med 361:1639-1650

55. Jungraithmayr TC, Bulla M, Dippell J, Greiner C, Griebel M, Leichter HE, Plank C, Tönshoff B, Weber LT, Zimmerhackl LB; German MMF Study Group (2005) Primary focal segmental glomerulosclerosis-long-term outcome after pediatric renal transplantation. Pediatr Transplant 9:226-231

56. Wühl E, Fydryk J, Wiesel M, Mehls O, Schaefer F, Schärer K (1998) Impact of recurrent nephrotic syndrome after renal transplantation in young patients. Pediatr Nephrol 12:529-533

57. Hubsch H, Montané B, Abitbol C, Chandar J, Shariatmadar S, Ciancio G, Burke G, Miller J, Strauss J, Zilleruelo G (2005) Recurrent focal glomerulosclerosis in pediatric renal allografts: the Miami experience. Pediatr Nephrol 20:210-216

58. Kidney Disease: Improving Global Outcomes (KDIGO) Transplant Work Group (2009) KDIGO clinical practice guideline for the care of kidney transplant recipients. Am J Transplant Suppl 3:S1-155

59. Seeman T (2009) Hypertension after renal transplantation. Pediatr Nephrol 24:959-972

60. Arbeiter K, Pichler A, Stemberger R, Mueller T, Ruffingshofer D, Vargha R, Balzar E, Aufricht C (2004) ACE inhibition in the treatment of children after renal transplantation. Pediatr Nephrol 19:222-226

61. Seeman T, Dusek J, Vondrak K, Janda J (2010) Ramipril in the treatment of proteinuria in children after renal transplantation. Pediatr Transplantation 14:283-287

62. Kidney Disease: Improving Global Outcomes (KDIGO) Blood Pressure Work Group (2012) KDIGO clinical practice guideline for the management of blood pressure in chronic kidney disease. Kidney Int Suppl 2:S337-414
63. Seeman T, Pohl M, Misselwitz J, John U (2009) Angiotensin receptor blocker reduces proteinuria independently of blood pressure in children already treated with Angiotensin-converting enzyme inhibitors. Kidney Blood Press Res 32:440-444

64. Lassila M, Cooper ME, Jandeleit-Dahm K (2004) Antiproteinuric effect of RAS blockade: new mechanisms. Curr Hypertens Rep 6: 383-392

65. Lurbe E, Cifkova R, Cruickshank JK, Dillon MJ, Ferreira I, Invitti C, Kuznetsova T, Laurent S, Mancia G, Morales-Olivas F, Rascher W, Redon J, Schaefer F, Seeman T, Stergiou G, Wühl E, Zanchetti A (2009) Management of high blood pressure in children and adolescents: recommendations of the european society of hypertension. J Hypertens 27:1719-1742

66. Seeman T, Simkova E, Kreisinger J, Vondrak K, Dusek J, Dvorak SH, Janda J (2007) Reduction of proteinuria during intensified antihypertensive therapy in children after renal transplantation. Transplant Proc 39:3150-3152

67. De Borst MH, Hajhosseiny R, Tamez H, Wenger J, Thadhani R, Goldsmith DJ (2013) Active vitamin D treatment for reduction of residual proteinuria: a systematic review. J Am Soc Nephrol 24: $1863-1871$

\section{Answers to questions}
1. d
2. d
3. c
4. b
5. c 